\title{
Article \\ Controlling Factors for Organic Carbon Burial in the Late Cretaceous Nenjiang Formation of the Songliao Basin, NE China
}

\author{
Lu Niu ${ }^{1,2}$, Yuan Gao ${ }^{1,2, *(\mathbb{D}, \text {, He Huang }}{ }^{1,2}$, Xing Tian ${ }^{1,2}$, Tian Dong ${ }^{1,2}$, Qian Yang ${ }^{1,2}$, Xiaomeng Cao ${ }^{3}$ \\ and Chengshan Wang ${ }^{1,2}$
}

1 State Key Laboratory of Biogeology and Environmental Geology, China University of Geosciences (Beijing), Beijing 100083, China; 2101190028@cugb.edu.cn (L.N.); huang1006@cugb.edu.cn (H.H.); tianxing@cugb.edu.cn (X.T.); tiandong@cugb.edu.cn (T.D.); 2101200045@cugb.edu.cn (Q.Y.); chshwang@cugb.edu.cn (C.W.)

2 School of Earth Science and Resources, China University of Geosciences (Beijing), Beijing 100083, China

3 Laboratory for Marine Geology, Pilot National Laboratory for Marine Science and Technology (Qingdao), Qingdao 266237, China; xmcao@qnlm.ac

* Correspondence: yuangao@cugb.edu.cn

Citation: Niu, L.; Gao, Y.; Huang, H.; Tian, X.; Dong, T.; Yang, Q.; Cao, X.; Wang, C. Controlling Factors for Organic Carbon Burial in the Late Cretaceous Nenjiang Formation of the Songliao Basin, NE China. Energies 2021, 14, 4783. https:// doi.org/10.3390/en14164783

Academic Editor: Hemanta Sarma

Received: 7 June 2021

Accepted: 27 July 2021

Published: 6 August 2021

Publisher's Note: MDPI stays neutral with regard to jurisdictional claims in published maps and institutional affiliations.

Copyright: (c) 2021 by the authors. Licensee MDPI, Basel, Switzerland. This article is an open access article distributed under the terms and conditions of the Creative Commons Attribution (CC BY) license (https:/ / creativecommons.org/licenses/by/ $4.0 /)$.

\begin{abstract}
The Songliao Basin (SLB) is a large terrestrial petroliferous basin located in northeastern China. The Nenjiang Formation represents excellent hydrocarbon source rocks for the Daqing oil field. Previous studies have indicated that the oil shale intervals from the first $\left(\mathrm{K}_{2} \mathrm{n}^{1}\right)$ and second $\left(\mathrm{K}_{2} \mathrm{n}^{2}\right)$ members of the Nenjiang Formation were formed in different depositional settings. In this study, we provide a new high-resolution (1 m interval) record from SK-1s core and compile three sets of published datasets from two drilling holes (Zk3389 and LY-1) and a composite outcrop section. According to the total organic carbon (TOC) chemostratigraphy, we have divided three variation cycles spanning from $\mathrm{K}_{2} \mathrm{n}^{1}$ to $\mathrm{K}_{2} \mathrm{n}^{2}$ and detected three potential oil shale intervals in the Nenjiang Formation. Combined with the productivity, salinity, and oxygenation proxies, we discuss the paleolimnological environmental changes during deposition of the Nenjiang Formation. Our new and compiled records support the model that excellent preservation conditions were associated with the formation of organic-rich sediments in the $\mathrm{K}_{2} \mathrm{n}^{1}$, while the productivity was the major controlling factor for organic matter enrichment in the $\mathrm{K}_{2} \mathrm{n}^{2}$.
\end{abstract}

Keywords: Songliao Basin; Nenjiang Formation; oil shale; organic matter enrichment

\section{Introduction}

The continental basin is an important carbon reservoir, playing a vital role in modulating the carbon cycle at multiple time scales [1,2]. The Songliao Basin was a long-lived terrestrial rift basin located in East Asia and preserved complete Cretaceous strata [3-5] (Figure 1). These geological archives provide invaluable information associated with the regional continental climate changes and the massive formation of lacustrine petroleum source rocks within the Cretaceous greenhouse world [1,3-10]. In terrestrial sedimentary basins, substantial studies have taken different factors into consideration when concerned about the formation of organic-rich strata, including tectonic settings, paleoclimate changes, primary productivity, redox conditions, and paleo-lake level [8,11-13].

The Qingshankou and Nenjiang Formations represent organic-rich sediments mainly deposited under a warm and humid climate background and provide a solid materials foundation for oil and gas exploration in Songliao Basin [4]. Previous studies widely discussed sedimentary environments during the deposition of the organic-rich intervals and simultaneously established a series of sedimentary models for interpretation of the oil shale development in the Qingshankou and Nenjiang Formations [1,4,8,12-19]. The stable and thick oil shale successions that developed at the bottom of $K_{2} q^{1}$ and $K_{2} n^{2}$ are accepted 
as marked layers throughout the Songliao Basin to correlate strata from different drilling holes and sections (references herein and in this study) [20]. Interestingly, prior studies have shown that two large marine transgressions occurred in the lower Qingshankou and Nenjiang Formations during the Late Cretaceous period, possibly indicating a causal linkage between oil shale development and seawater incursion events [7,21-24].

(a)

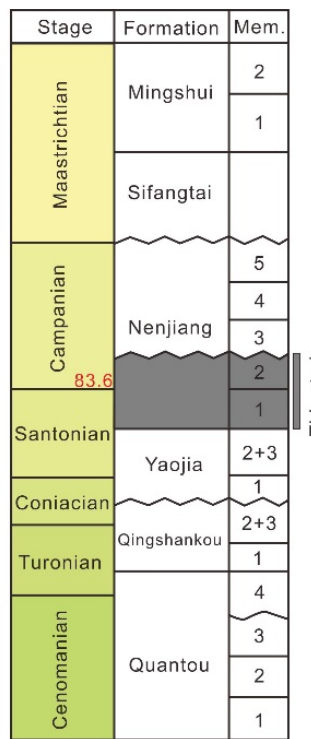

(d)
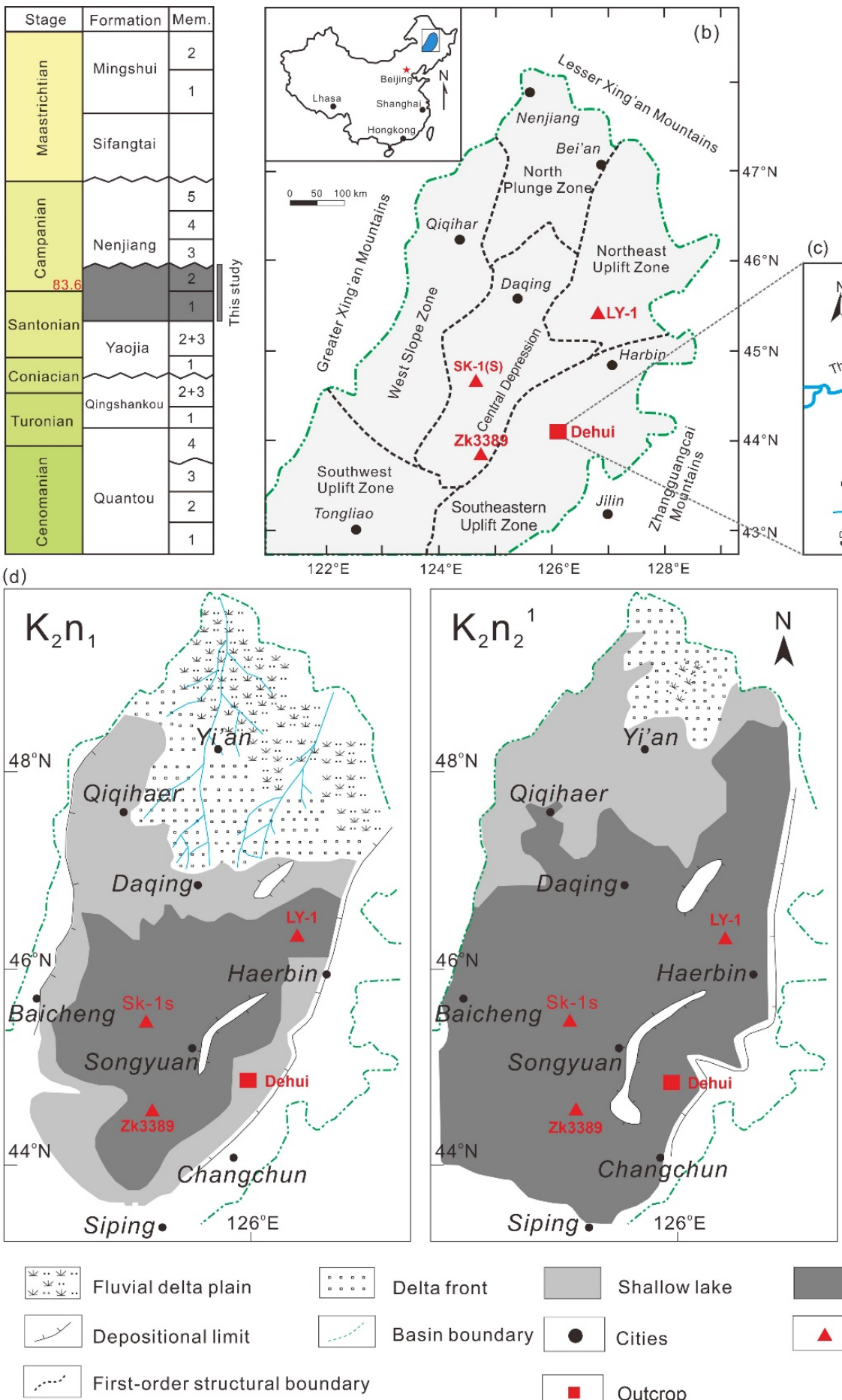
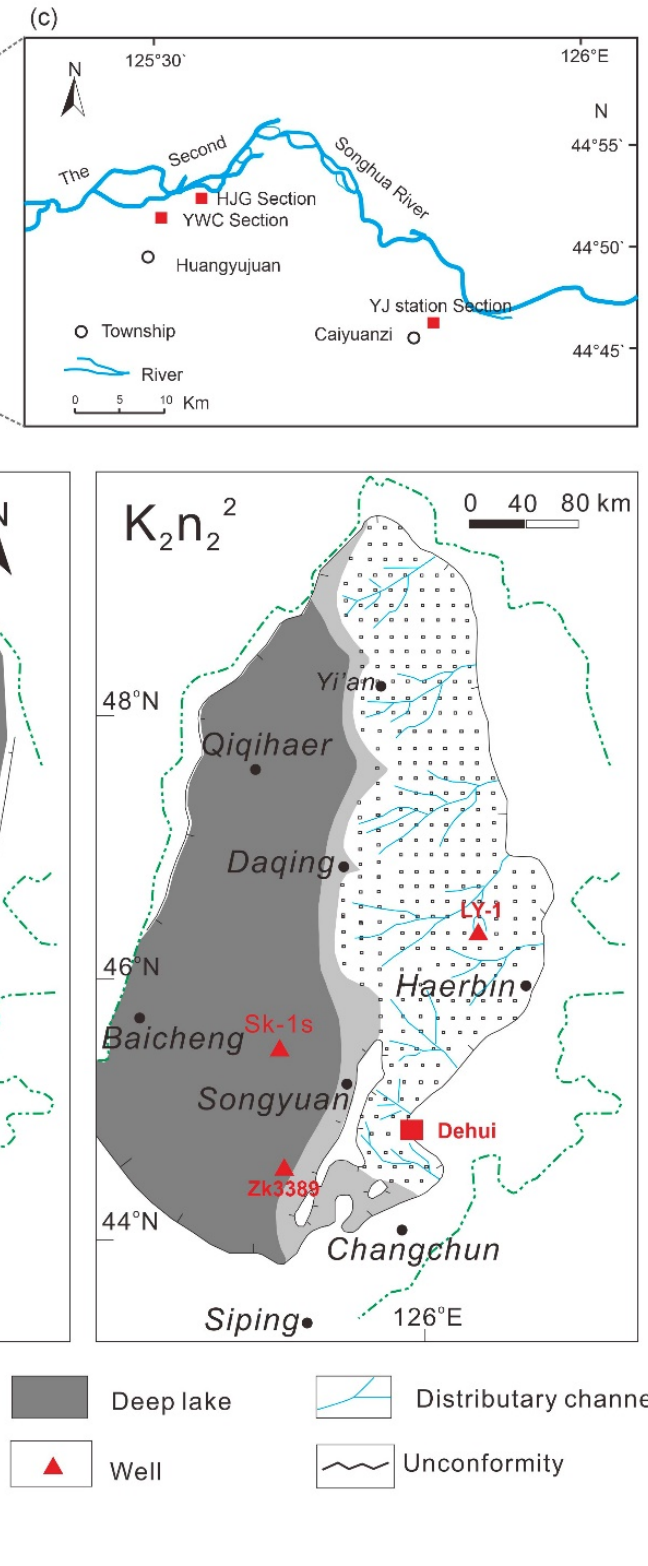

Deep lake

$\square$ Distributary channel

Well

Unconformity

Figure 1. Geological setting of the Nenjiang Formation. (a) Geological time framework of SK-1s core, the dashed area represents the study interval ( $1+2$ member of Nenjiang Formation). (b) Geographic distribution of the SK- 1 core and compiled study sites, modified from [6]. (c) The composite section located in Dehui area, modified from [7]. (d) The evolution of the sedimentary facies of Nenjiang Formation from $K_{2} n^{1}$ to $K_{2} n^{2}$, modified from [8]. 
The Nenjiang Formation contains two sets of economic hydrocarbon source rocks in the lower $\mathrm{K}_{2} \mathrm{n}^{1}$ and $\mathrm{K}_{2} \mathrm{n}^{2}$ (Figure 2). Several lines of evidence from geochemical proxies indicate that these two suits of oil shale formed in two distinct depositional environments [8]. According to the hydrogen index (HI), kerogen types, n-alkanes, and carbon isotope, the organic matter in $K_{2} n^{1}$, largely originated from algal organisms [12,25]. In $K_{2} n^{1}$, a line of evidence, including the discovery of foraminifera [21], marine-specific biomarkers [23,25], and sulfur isotope [22], indicate that multiple marine incursion events occurred during the deposition of the lower $\mathrm{K}_{2} \mathrm{n}^{1}$. Marine incursion events provided a plausible environment for the formation of the oil shale under a stratified and anoxic bottom-water condition $[5,12,13,23]$. The oil shale in lower $\mathrm{K}_{2} \mathrm{n}^{2}$ was deposited during the largest lacustrine transgression inferred from the distribution of the black shales exceeding the present basin's boundary [26]. The organic matter in the $\mathrm{K}_{2} \mathrm{n}^{2}$ was largely derived from algal and bacterial sources and combined with a gradual increase in land-plant input $[8,12,19,25]$. The organic geochemical data also indicate significantly different depositional environments for this oil shale interval $[8,12,18,19]$. Recently, a compound-specific isotope study indicated a dramatically wet climate occurred during the Santonian-Campanian transition (roughly corresponding to the oil shale interval in lower $\mathrm{K}_{2} \mathrm{n}^{2}$ ) [27]. The rapid hydroclimate change might cause high TOC content through enhancing terrigenous nutrients into the lake [22,27]. However, the geochemical records from the composite section in southern Songliao Basin raised another possible organic-rich explanation for the $\mathrm{K}_{2} \mathrm{n}^{2}$ oil shale interval $[23,24]$. Therefore, the relationship between the depositional environments and the development of organic-rich sediments within the Nenjiang Formation is still ambiguous $[19,24]$. A comprehensive understanding of the mechanism of the formation of the organic-rich strata (i.e., Nenjiang Formation) is essential for further oil/gas exploration in the Songliao Basin.

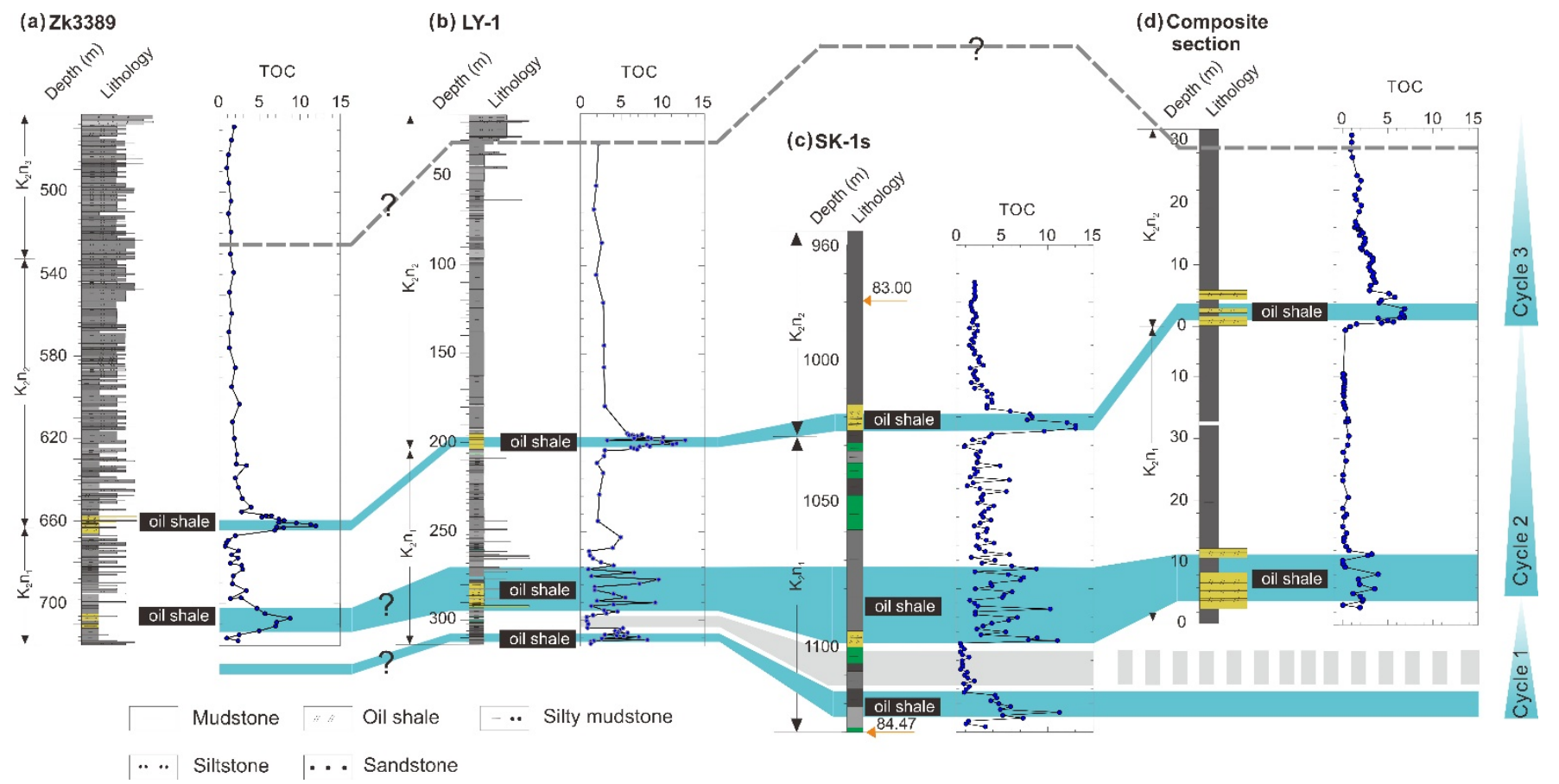

Figure 2. TOC chemostratigraphic records from the Nenjiang Formation and stratigraphic correlation with four sets of TOC records based on the TOC variation patterns. (a) The TOC curve from Zk3389 well [8]. (b) The TOC records from the LY-1 drilling core [18]. (c) The new TOC records from SK-1s. (d) The TOC records compiled from the composite section [7].

Here, we provide new TOC data in Nenjiang Formation from the SK-1s core and simultaneously compile the published TOC data from another two drilling cores (i.e., Zk3389, LY-1) and a composite outcrop section located in the southeastern Songliao Basin 
(Figure 1). Moreover, we compile the published biomarker, element concentration, redox proxies, and paleo-salinity proxies (Table 1) to discuss (1) the controlling factors to the formation of the organic-rich strata; (2) the spatial difference of sedimentary environment in the first and second members of the Nenjiang Formation; (3) the formation mechanisms of oil shale intervals in the first and second members of the Nenjiang Formation, respectively.

Table 1. Definition of paleoenvironmental proxies used in this study.

\begin{tabular}{|c|c|}
\hline Proxies & Definition \\
\hline TOC & $\begin{array}{l}\text { Total organic carbon (TOC) content for whole rock sample, the TOC } \\
\text { content is an important proxy for predicting the presence of oil shale and } \\
\text { has widely been used in petroleum geological field. }\end{array}$ \\
\hline $\mathrm{P} \%$ & $\begin{array}{l}\text { Phosphorus }(\mathrm{P}) \text { contents are linked to primary productivity, because } \mathrm{P} \text { is } \\
\text { the limiting nutrient in lakes. }\end{array}$ \\
\hline $\mathrm{Pr} / \mathrm{Ph}$ & $\begin{array}{l}\mathrm{Pr} / \mathrm{Ph} \text { has been widely used as an indicator of depositional redox } \\
\text { conditions, with } \mathrm{Pr} / \mathrm{Ph}>3 \text { indicative of oxic to suboxic depositional } \\
\text { conditions, while } \mathrm{Pr} / \mathrm{Ph}<0.8 \text { indicates saline to hypersaline and /or } \\
\text { anoxic conditions. }\end{array}$ \\
\hline $\mathrm{Sr} / \mathrm{Ba}$ & $\begin{array}{l}\text { The Sr/Ba ratio is widely regarded as an empirical indicator of } \\
\text { paleosalinity. A high } \mathrm{Sr} / \mathrm{Ba} \text { ratio reflects high salinity, and a low } \mathrm{Sr} / \mathrm{Ba} \\
\text { ratio indicates low salinity. }\end{array}$ \\
\hline $\mathrm{V} / \mathrm{Ni}$ & $\begin{array}{l}\text { Vanadium }(\mathrm{V}) \text { and nickel }(\mathrm{Ni}) \text { are important indicators for the redox } \\
\text { conditions. } \mathrm{V} \text { is usually enriched in comparison with } \mathrm{Ni} \text { in anoxic } \\
\text { environments. Generally, a high } \mathrm{V} / \mathrm{Ni} \text { ratio reflects reducing conditions, } \\
\text { and a low ratio indicates oxidizing conditions. }\end{array}$ \\
\hline GI & $\begin{array}{l}\text { Gammacerane index (GI) is widely regarded as an empirical indicator of } \\
\text { paleosalinity and possibly a marker for photic zone anoxia. }\end{array}$ \\
\hline MTTC & $\begin{array}{l}\text { Methyltrimethyltridecyl chromans (MTTCs) are structurally similar to } \\
\text { tocopherols (vitamin E) but with a hydrogen replacing an OH at C-6. The } \\
\text { MTTC ratios are widely used as indicators of paleosalinity. }\end{array}$ \\
\hline $\mathrm{Ca} / \mathrm{Mg}$ & $\begin{array}{l}\mathrm{Ca} / \mathrm{Mg} \text { ratios in sediments can provide information on salinity variation } \\
\text { during their deposition. High values have been considered to reflect } \\
\text { saline water. }\end{array}$ \\
\hline
\end{tabular}

\section{Geological Background}

The Songliao Basin is located in northeast China and covers an area of roughly $260,000 \mathrm{~km}^{2}$ in the Liaoning, Jilin, and Heilongjiang provinces (Figure 1). The basin trends in NNE direction and geographically lies between $119^{\circ} 40^{\prime} \mathrm{E}$ to $128^{\circ} 24^{\prime} \mathrm{E}$ and $42^{\circ} 25^{\prime} \mathrm{N}$ to $49^{\circ} 23^{\prime} \mathrm{N}$ [3]. A long-lived Jurassic to Cretaceous stratigraphic record was preserved in a deep back-arc rifted sag basin $[3,28]$. The Mesozoic-Cenozoic terrestrial strata with an uneven thickness consist of volcanic, volcaniclastic, alluvial-fan, fluvial, and lacustrine sediments (Figure 2) [29]. An ICDP drilling project recovered a sedimentary succession spanning the mid-Turonian to Campanian in two cores (SK-1s and SK-1n) in 2009 [3]. The SK-1s hole has intercepted four formations, ranging from Member 3 of the Quantou Formation $\left(\mathrm{K}_{2} \mathrm{q}^{3}\right)$ in the bottom to Member 2 of the Nenjiang Formation $\left(\mathrm{K}_{2} \mathrm{n}^{2}\right)$ at the top.

The Nenjiang Formation, which is the focus of this study, was sub-divided into five members, but only Members 1 and 2 developed organic-rich sediments. Members 1 and 2 of the Nenjiang Formation consist of grey to black mudstones and inter-bedded with many thin and ellipsoidal dolomite beds [30]. The depositional environment of Members $1+2$ of the Nenjiang Formation was regarded as a deep lacustrine facies [2]. The studied interval in the Nenjiang Formation spans the Santonian to Campanian of the Late Cretaceous period. Its age model is well constrained by biostratigraphy, magnetostratigraphy, cyclostratigraphy, and $\mathrm{U}-\mathrm{Pb}$ radioisotope geochronology [6,31-33]. 


\section{Methods}

Samples for this study were collected from SK-1s at a uniformly spaced $1 \mathrm{~m}$ from the first and second members of Nenjiang Formation. A total of 157 samples were collected from the $157 \mathrm{~m}$ (1127-970 m)-thick core in the core repository of the China University of Geosciences (Beijing). The samples were cleaned with distilled water, dried at $50{ }^{\circ} \mathrm{C}$, and then, crushed to 200 mesh. The $2 \mathrm{~N} \mathrm{HCL}$ was added to approximately $0.5 \mathrm{~g}$ of sample powder and allowed to react for $\sim 24 \mathrm{~h}$ to remove the carbonate fraction. The residues, including siliciclastic grains, pyrite, and organic matter, were then washed with deionized water until solutions reached neutral $\mathrm{pH}$ prior to drying in a $60{ }^{\circ} \mathrm{C}$ oven overnight. The dried residues were quantified in order to calculate \% carbonate in the bulk samples; aliquots of between 0.5 and $5 \mathrm{mg}$ were weighed into tin cups for organic carbon determinations.

Measurements for organic carbon abundance was packed with chromium oxide and silvered cobaltous/cobaltic oxide and heated to over $950{ }^{\circ} \mathrm{C}$. The analyte also flowed through a second column at $950{ }^{\circ} \mathrm{C}$ packed with high-purity reduced copper wire for quantitative reduction in $\mathrm{NO}_{2}$ and $\mathrm{N}_{2} \mathrm{O}$ and $\mathrm{O}_{2}$ resorption, as well as a $\mathrm{Mg}\left(\mathrm{ClO}_{4}\right)_{2}$ desiccant column to remove water. The $\mathrm{CO}_{2}$ was separated from other gases with a 3-meter stainless steel GC column packed with Porapak-Q heated to $60^{\circ} \mathrm{C}$.

Standard samples were measured between each set of 6 samples and uncertainties for each analytical session based on these standard analyses were determined to be better than $0.2 \%$, for organic carbon abundance composition. Total organic carbon contents were calculated by quantifying the \% carbonate in the bulk samples and IRMS $\mathrm{CO}_{2}$ peak areas relative to those from measured amounts of standards. The TOC content was analyzed by Vario E L Cube organic element analyzer in the State Key Laboratory of Marine Geology, Tongji University, Shanghai.

\section{Results and Discussion}

The Nenjiang Formation have been conducted comprehensive research on geology, sedimentology, geochemistry, paleontology, and paleoclimate, but there is a lack of highresolution geological records and spatial correlation research, thus understanding of the mechanism of oil shale formation in Nenjiang Formation is still insufficient. Here, we provide high-resolution TOC data and compile published geochemical data for spatial comparison and, further, comprehensively discuss the division, distribution, and formation mechanism of the oil shales.

\subsection{TOC Variations and Spatial Correlation}

Chemostratigraphic correlation is mainly based on the geochemical records and their variation trend, abnormal characteristics (extremum), and event signals. Especially in marine stratigraphic records, chemostratigraphy is extensively used, including carbon isotope stratigraphy, oxygen isotope stratigraphy, strontium isotope stratigraphy, etc. As the largest sedimentary basin in East Asia during the Cretaceous period, the Songliao basin has great potential for multi-temporal and spatial scale geochemical comparative studies $[1,9,10,34]$. Jones et al. (2018) compared the organic carbon isotope data of the Qingshankou Formation with the western interior basin in North America and revealed oceanic anoxic event 3 (OAE3) in the continental sedimentary basin for the first time. The Songliao basin has the biggest lake areas and relatively stable geochemical characteristics during the deposition of the Nenjiang Formation, thus it is possible to conduct stratigraphic correlation research within the basin [15].

In this study, we established the high-resolution TOC chemostratigraphy of the first and second members of Nenjiang Formation. Combined with the previous research results, we made a comparative study of TOC records and further revealed the consistency and difference characteristics of organic carbon burial in the Nenjiang Formation of the Songliao basin.

In general, the trend of TOC data of the first and second members of the Nenjiang Formation in the SK-1s well is consistent with the previous results $[7,12]$, but with more 
abundant high-frequency variations characteristics (Figure 2). Song et al. (2013) divided the TOC values from the Nenjiang Formation into four sections in SK-1s. In this part, we adopt their division scheme to describe the change in TOC. Part I (1128-1117 m): the TOC content in this section firstly increased and then decreased, with an average of $4.9 \%$ and reached to the maximum at $11.26 \%$; part II $(1116-1099 \mathrm{~m})$ : the TOC content in this part is very low, ranging from 0.44 to $1.41 \%$, with an average of $0.9 \%$; part III (1099-1026 m): the TOC content of this section has changed greatly and presents a decreased trend with fluctuated variations, with an average content of 3.5\%; part IV(1025-973 m): this part includes all the TOC records of the second member of Nenjiang Formation in SK-1s hole. From the oil shale interval, the TOC content is extremely high and rapidly decreases upward, basically maintaining a relatively stable TOC values (2-3\%).

The strata of Nenjiang Formation can be comparative in the whole basin. We collected two wells (Zk3389 and LY-1) and one composite profile and compared their strata according to the TOC datasets with SK-1s TOC records. Among them, the oil shale at the bottom of the second member of the Nenjiang Formation is not only comparable from lithological viewpoint in the whole basin, but also consistent in high TOC value, so it can be used as a marker layer for stratigraphic correlation within the Nenjiang Formation [4,35]. In Zk3389, the variation trend of TOC data of the Nenjiang Formation shows two cycles from high value to low value, and the two high values of TOC represent two potential oil shales $[8,18]$. In LY-1 well, the variation trend of TOC is basically consistent with that of SK-1s. It is obvious that there are three organic rich intervals, which may indicate three potential oil shale layers. In the composite profile, the most obvious characteristic is that the bottom of $\mathrm{K}_{2} \mathrm{n}^{2}$ has a high TOC content; meanwhile, the bottom of $\mathrm{K}_{2} \mathrm{n}^{1}$ also has about $10 \mathrm{~m}$ thick high TOC intervals. These two sets of high TOC intervals may represent two layers of oil shale.

Combined with the TOC records of SK-1s, we made horizontal correlation and stratigraphic division of the four sets of TOC data according to the correlation principles of chemostratigraphy. We defined the TOC change pattern from high value to low value and then shift to high value as a complete cycle. Exemplified from the SK-1s, we divided the TOC curve into three cycles (Figure 2). In the other three TOC data records, the TOC profile from well LY-1 also has three cycles. However, Zk3389 and the composite section TOC data can only be divided into two TOC change cycles, which may indicate the presence of strata hitas. According to our comparison results, we noticed that the TOC curves from Zk3389 and profile are lack of oil shale interval at the bottom of $\mathrm{K}_{2} \mathrm{n}^{1}$. From the high TOC values records in the middle of $\mathrm{K}_{2} \mathrm{n}^{1}$, the general trend of the four TOC datasets shows a high degree of consistency.

As mentioned above, the oil shale intervals in Nenjiang Formation are consistent well with the high TOC values [8,18], although their results have only evaluated two potential oil shale intervals in the Nenjiang Formation due to the low resolution of TOC data or presence of strata hitas. Additionally, the lithological associations of Nenjiang Formation mainly consist of grey to black mudstone, and their TOC background values are basically below 3\%, while the oil shale intervals have extremely high TOC content, which can reach $\sim 14 \%$ (Figure 2 ). Therefore, we conclude that the TOC content could be a useful indicator, in part, for predicating the presence of oil shale in Nenjiang Formation. Besides, TOC content as an indicator for shale oil presence also has been used in Bohai Bay Basin (Shahejie Formation), Sichuan Basin (Wufeng and Longmaxi Formation), and Junggar Basin (Lucaogou and Fengcheng Formation). Therefore, according to the TOC values, we have identified three potential oil shale intervals in the Nenjiang Formation from the SK-1s well; they are located at the bottom of $K_{2} n^{1}$ member (1125-1115 m), the middle of $\mathrm{K}_{2} \mathrm{n}^{1}$ member (1099-1070 m), and the bottom of $\mathrm{K}_{2} \mathrm{n}^{2}$ member (1024-1016 m) (Figure 2). Obviously, the distribution of the three high-TOC segments is different among the four sets' records. Collectively, the oil shale in $\mathrm{K}_{2} \mathrm{n}^{2}$ is relatively stable throughout the whole basin, with an average thickness of $10 \mathrm{~m}$. The oil shale in the middle of $\mathrm{K}_{2} \mathrm{n}^{1}$ with an average thickness up to $20 \mathrm{~m}$ and characterized by "thick in the south and thin in the north". While 
the oil shale in the bottom of $\mathrm{K}_{2} \mathrm{n}^{1}$ is relatively thin, generally $3-5 \mathrm{~m}$, only in SK-1s drilling core, the thickness can reach to $10 \mathrm{~m}$.

Based on the oil shale thickness information, average TOC values, and the distribution areas of oil shale [36], we can roughly calculate the amount of organic carbon burial flux in the north part of Songliao Basin. Because of the incomplete development of the oil shale interval in the bottom of $\mathrm{K}_{2} \mathrm{n}^{1}$ and lack of distribution area information, we only calculate the two oil shale intervals in the middle of $K_{2} n^{1}$ and bottom of $K_{2} n^{2}$. The oil shale in the middle of $\mathrm{K}_{2} \mathrm{n}^{1}$ has an average thickness of $\sim 20 \mathrm{~m}$ and a distribution area of $21,000 \mathrm{~km}^{2}$, with an average TOC of $3.85 \%$ (calculated from three drilling cores and a composite section). The calculated organic carbon burial of the oil shale in the middle of $\mathrm{K}_{2} \mathrm{n}^{1}$ is $4.0 \times 10^{16} \mathrm{gC}$ (Table 2). Using the same calculation formulation, we have obtained the amount of organic carbon burial flux $\left(2.6 \times 10^{16} \mathrm{gC}\right)$ of oil shale interval in the bottom of $\mathrm{K}_{2} \mathrm{n}^{2}$ (Table 2). Taking the oil generation efficiency $(\sim 348 \mathrm{mg} / \mathrm{g})$ into account, the potential unconventional oil resources of Nenjiang Formation can reach to $229 \times 10^{8} t$, which is very close to $\mathrm{Wu}$ et al. (2019) calculation results (i.e., $211 \times 10^{8} \mathrm{t}$ ).

Table 2. Organic carbon burial in two oil shale intervals of Nenjiang Formation in north part of Songliao Basin.

\begin{tabular}{ccc}
\hline & The Middle of $\mathbf{K}_{\mathbf{2}} \mathbf{n}^{\mathbf{1}}$ & The Bottom of $\mathbf{K}_{\mathbf{2}} \mathbf{n}^{\mathbf{2}}$ \\
\hline Area $\left(\mathrm{Km}^{2}\right)$ & 21,000 & 20,000 \\
\hline Thickness $(\mathrm{m})$ & 20 & 10 \\
\hline Average TOC $(\%)$ & 3.85 & 5.2 \\
\hline Oil shale density $\left(\mathrm{g} / \mathrm{cm}^{3}\right)$ & 2.5 & 2.5 \\
\hline OC burial $(\mathrm{gC})$ & $4.0 \times 10^{16}$ & $2.6 \times 10^{16}$ \\
\hline Total OC burial $(\mathrm{gC})$ & $6.6 \times 10^{16}$ \\
\hline
\end{tabular}

\subsection{The Controlling Factors for Organic Matter Enrichment in the Nenjiang Formation}

The enrichment of organic matter and the formation of oil and gas resources are very complex processes, involving many interrelated sedimentary processes and controlling factors. Generally speaking, primary productivity, preservation conditions, and dilution of terrigenous detritus are the three most important factors affecting the enrichment of organic matter in the lake catchment [11]. These three factors are closely related to the global/regional climate change and lake water biogeochemical characteristics [18]. Moreover, recent studies also state clearly that the driving force of astronomical orbit controls the enrichment of organic matter $[14,37,38]$. The Songliao Basin, as the largest paleolake in East Asia during the Cretaceous, is rich in oil and gas resources. The mechanisms related to enrichment of organic matter have been extensively studied. Lacustrine water column salinity stratification during the Qingshankou and Nenjiang Formations facilitated the formation of dysoxic-anoxic conditions at the lake bottom, favoring organic matter preservation and carbon sequestration into organic-rich black shale $[1,8,12,13,18,22]$. However, the relationship between the change in bottom water conditions and the enrichment of organic matter is still controversial (e.g., Qingshankou Fm. [1]). In this study, we compiled salinity, redox, and other indicators that matched with TOC data to discuss the relationship between bottom water environments and the TOC variations.

In $\mathrm{Zk3389}$, the redox index (V/Ni; $\mathrm{Pr} / \mathrm{Ph})$ in $\mathrm{K}_{2} \mathrm{n}^{1}$ and $\mathrm{K}_{2} \mathrm{n}^{2}$ shows two different trends. In $\mathrm{K}_{2} \mathrm{n}^{1}$, the redox proxies indicate a partial reduction in bottom water environment, while in $\mathrm{K}_{2} \mathrm{n}^{2}$, more oxidation environment was inferred from the V/Ni and $\mathrm{Pr} / \mathrm{Ph}$ paleoredox indicators. The salinity index (Sr/Ba; MTTC, GI) of $\mathrm{K}_{2} \mathrm{n}^{1}$ and $\mathrm{K}_{2} \mathrm{n}^{2}$ also showed obvious differences. Generally, the salinity of $K_{2} n^{1}$ was higher than that of $K_{2} n^{2}$. In addition, the salinity index and redox index have a good synergistic change, which may indicate the causal relationship between salinity stratification and anoxic environment (Figures 3 and 4). 


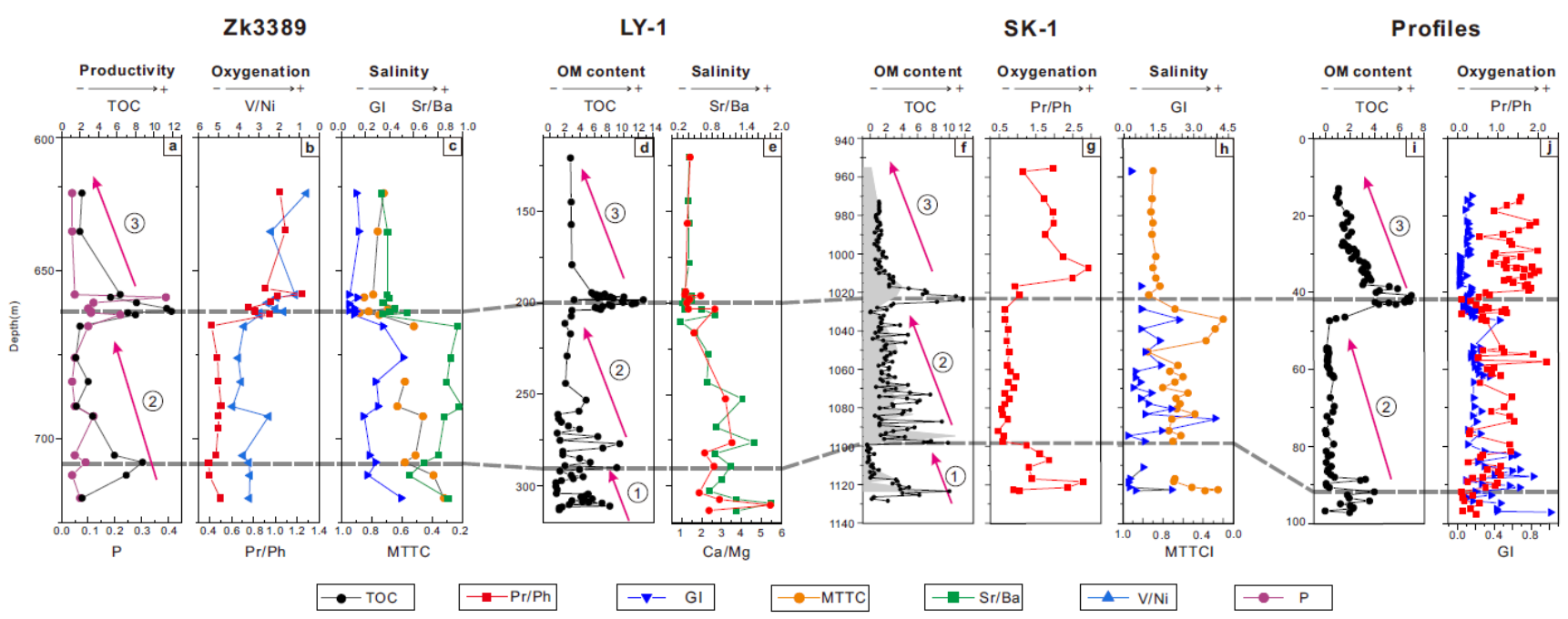

Figure 3. Environmental proxies from the Nenjiang Formation Member 1 and Member 2 from four study sites. Productivity proxies including TOC and P concentration; redox indictors including the trace elements ratios (V/Ni) and biomarkers (GI; $\mathrm{Pr} / \mathrm{Ph}$ ); the paleosalinity conditions during the study interval deduced from the $\mathrm{Sr} / \mathrm{Ba}$ ratios, $\mathrm{Ca} / \mathrm{Mg}$ ratios, MTTC, and gammacerane index (GI). (a) The Zk3389 TOC and P element content [8]; (b) The oxygenation indicators (V/Ni and Pr/Ph) from Zk3389 core samples [8]; (c) The salinity proxies (GI, Sr/Ba and MTTC) of Zk3389 [8]; (d) The TOC content of LY-1 core [18]; (e) The salinity proxies (Sr/Ba and Ca/Mg ratios) of LY-1 drilling core [18]; (f) The TOC content of SK-1s core; (g) The Pr/Ph ratios as a oxygenation index for SK-1s [13]; (h) Paleosalinity biomarker proxies (MTTCI and GI) of SK-1s [13]; (i) The TOC content of the composite section [7]; (j) The oxygenation proxies (Pr/Ph, GI) of the composite section [7]. The pink arrow (1)-(3) in the picture: the three change cycles of TOC.
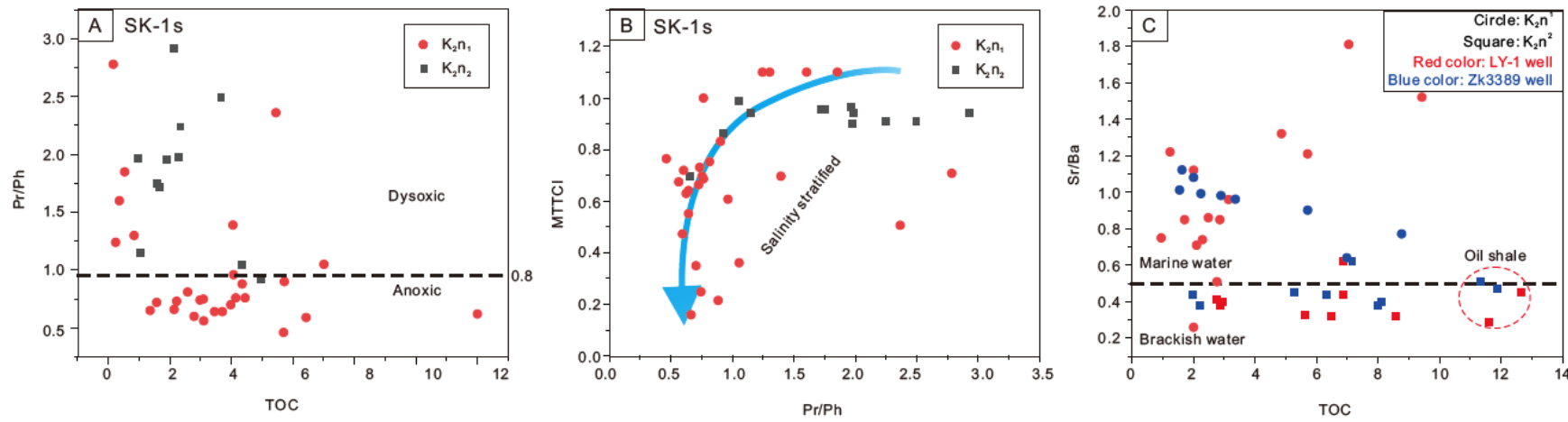

Figure 4. Cross-plot of paleoenvironmental proxies for the Nenjiang Formation in the Songliao Basin. (A) Correlation analysis of the TOC and Pr/Ph ratios for the Nenjiang Formation samples from SK-1s. (B) The MTTCI and Pr/Ph cross plot indicated a salinity stratified bottom water conditions for $\mathrm{K}_{2} \mathrm{n}_{1}$. (C) Cross-plot of TOC versus Sr/Ba ratios for the LY-1 and Zk3389 wells, showing different enrichment mechanism of organic-rich sediments between $\mathrm{K}_{2} \mathrm{n}^{1}$ and $\mathrm{K}_{2} \mathrm{n}^{2}$.

The paleosalinity proxies from LY-1 revealed similar salinity features by comparing them with the Zk3389 drilling hole records (Figure 3). In the three TOC cycles, redox indicators from the SK-1s presented distinct variabilities. In cycle 1, the high TOC interval is associated with the reduction bottom water environments, while low TOC corresponds to the oxygenated bottom water conditions. In cycle 2, The bottom water condition is reductive, and the TOC data present a fluctuating decreased trends. Therefore, in this interval, the preservation conditions may not the only controlling factor for formation of the high TOC value, the productivity of the lake or terrestrial input may also have an impact on the change in TOC. In addition, the salinity index also shows high-frequency variations in this section, which may indicate the periodic input of fresh water. However, the redox index from the composite section has little change in the first and second members of the Nenjiang Formation, which cannot be used to evaluate the redox information recorded in the section. 
In summary, the geochemical data from drilling holes seem more suitable to reflect the relationship between lake bottom water environments and TOC variations than profile records. The salinity stratified and anoxic bottom water environments in $\mathrm{K}_{2} \mathrm{n}^{1}$ basically corresponds to the high TOC intervals (Figure 3). While the oil shale interval in $\mathrm{K}_{2} \mathrm{n}^{2}$ was featured by low salinity and relatively oxidized bottom water environments. Therefore, the formation conditions of the high TOC intervals in $\mathrm{K}_{2} \mathrm{n}^{1}$ and $\mathrm{K}_{2} \mathrm{n}^{2}$ seem different, which may represent two mechanisms of organic matter enrichment.

The bottom water environments of the $\mathrm{K}_{2} \mathrm{n}^{1}$ are more conducive to the preservation of organic matter. According to the P concentration from Zk3389, the productivity change in the first Nenjiang Formation is not obvious and basically remains stable (Figure 3). Therefore, the productivity has little effect on the enrichment of TOC. The enrichment of organic matter in the $\mathrm{K}_{2} \mathrm{n}^{1}$ is mainly due to favorable preservation conditions. Previous studies have shown that the high salinity, stratified, and anoxic bottom water environment may be caused by intermittent transgression provided a favorable preservation condition for organic matter preservation. In recent years, marine fossils, biomarkers, and isotopes from the $\mathrm{K}_{2} \mathrm{n}^{1}$ indicate that intermittent transgression occurred in the Songliao Basin during the Nenjiang Formation [5,12,21-24,39]. When the high-salinity seawater enters the lake, it would cause a series of changes in the biochemical balance of the lake water body. This process has been discussed by a recent study [40]. However, the understanding of the enrichment model and its phase characteristics between transgression events and TOC variations are still deficient and need future evaluation.

The water environment of the oil shale at the bottom of $\mathrm{K}_{2} \mathrm{n}^{2}$ is quite different from that of $\mathrm{K}_{2} \mathrm{n}^{1}$. According to the P concentration from the $\mathrm{Zk} 3389$ well, the primary productivity of the lake in this period is higher than that of $\mathrm{K}_{2} \mathrm{n}^{1}$, although the water environment is more oxidized (Figure 3). When the primary productivity is very high, the deposition rate and amount of organic matter will increase correspondingly. When the organic matter settles to the bottom of the lake, part of the organic matter is decomposed and oxygen is consumed; however, due to the high deposition rate, a large amount of organic matter is still buried and preserved [41]. $P$ is a relatively poor nutrient element in lake environment, mainly from terrestrial input [42]. The high content of $P$ element in oil shale of $K_{2} n^{2}$ may represent an intensive terrestrial input. Gravity flow deposits were also developed in this period [43]. Besides, the hydrogen isotopes of n-alkanes also show abnormal variation under the oil shale strata, indicating the abnormal water circulation process in this period [26]. Therefore, this evidence may indicate that the hydrological cycle of the Songliao Basin was strengthened and the source-to-sink system was changed, resulting in an increased terrestrial input, and ultimately leading to the lake became eutrophic. Therefore, the "productivity" model is the dominant factor for the formation of oil shale in $\mathrm{K}_{2} \mathrm{n}^{2}$.

\section{Conclusions}

In this study, we provided a new high-resolution TOC record from SK-1s core and compiled another three records from two drilling holes and a composite outcrop section to discuss the organic carbon burial mechanisms in the Nenjiang Formation. Three potential oil shale layers are present in the Upper Cretaceous Nenjiang Formation of the Songliao Basin. The oil shale interval in $\mathrm{K}_{2} \mathrm{n}^{2}$ was a marker layer, which can be tracked in the whole basin. Therefore, based on the marker layer and the geochemical data variation patterns, we have correlated the four sets of geochemical records and discussed their similarities and differences in response to depositional environments. Excellent preservation conditions were responsible for the formation of the organic-rich sediments in the oil shale in $K_{2} n^{1}$, while primary productivity is the major controlling factor for OM enrichment in the oil shale layer in $\mathrm{K}_{2} \mathrm{n}^{2}$.

Author Contributions: Conceptualization, L.N., Y.G. and C.W.; data curation, L.N.; formal analysis, L.N.; investigation, L.N.; methodology, L.N. and Y.G.; resources, C.W.; supervision, Y.G.; visualization, L.N.; writing—original draft, L.N.; writing—review and editing, Y.G., H.H., X.C., X.T., Q.Y., T.D. All authors have read and agreed to the published version of the manuscript. 
Funding: This study was supported by the National Natural Science Foundation of China (41972096, 41790452) and the Fundamental Research Funds for the Central Universities of China (2652018119).

Data Availability Statement: All data needed to evaluate the conclusions in the paper are present in the paper. Additional data related to this paper may berequested from the authors.

Acknowledgments: We thank editor Alina Vasica and two anonymous reviewers helpful and constructive comments. We also deeply thank Lei Kang, Chen Lingdi, and Liu Zhifei for accessing the analytical facilities at Tongji University.

Conflicts of Interest: The authors declare no conflict of interest.

\section{References}

1. Jones, M.M.; Ibarra, D.E.; Gao, Y.; Sageman, B.B.; Selby, D.; Chamberlain, C.P.; Graham, S.A. Evaluating Late Cretaceous OAEs and the influence of marine incursions on organic carbon burial in an expansive East Asian paleo-lake. Earth Planet. Sci. Lett. 2018, 484, 41-52. [CrossRef]

2. Laurin, J.; Meyers, S.R.; Uličný, D.; Jarvis, I.; Sageman, B.B. Axial obliquity control on the greenhouse carbon budget through middle to high-latitude reservoirs. Paleoceanography 2015, 30, 133-149. [CrossRef]

3. Wang, C. Environmental/climate change in the Cretaceous greenhouse world: Records from Terrestrial scientific drilling of Songliao Basin and adjacent areas of China. Palaeogeogr. Palaeoclim. Palaeoecol. 2013, 385, 1-5. [CrossRef]

4. Wang, C.; Feng, Z.; Zhang, L.; Huang, Y.; Cao, K.; Wang, P.; Zhao, B. Cretaceous paleogeography and paleoclimate and the setting of SKI borehole sites in Songliao Basin, northeast China. Palaeogeogr. Palaeoclim. Palaeoecol. 2013, 385, 17-30. [CrossRef]

5. Wang, C.S.; Scott, R.W.; Wan, X.Q.; Graham, S.A.; Huang, Y.J.; Wang, P.J.; Wu, H.C.; Dean, W.E.; Zhang, L.M. Late Cretaceous climate changes recorded in Eastern Asian lacustrine deposits and North American Epieric sea strata. Earth Sci. Rev. 2013, 126, 275-299. [CrossRef]

6. Wang, T.T.; Ramezani, J.; Wang, C.S.; Wu, H.C.; He, H.Y.; Bowring, S.A. High-precision U-Pb geochronologic constraints on the Late Cretaceous terrestrial cyclostratigraphy and geomagnetic polarity from the Songliao Basin, Northeast China. Earth Planet. Sci. Lett. 2016, 446, 37-44. [CrossRef]

7. Tong, X.; Hu, J.; Xi, D.; Zhu, M.; Song, J.; Peng, P. Depositional environment of the Late Santonian lacustrine source rocks in the Songliao Basin (NE China): Implications from organic geochemical analyses. Org. Geochem. 2018, 124, 215-227. [CrossRef]

8. Jia, J.; Bechtel, A.; Liu, Z.; Strobl, S.A.; Sun, P.; Sachsenhofer, R. Oil shale formation in the Upper Cretaceous Nenjiang Formation of the Songliao Basin (NE China): Implications from organic and inorganic geochemical analyses. Int. J. Coal Geol. 2013, 113, 11-26. [CrossRef]

9. Chamberlain, C.P.; Wan, X.; Graham, S.A.; Carroll, A.R.; Doebbert, A.C.; Sageman, B.B.; Blisniuk, P.; Kent-Corson, M.L.; Wang, Z.; Chengshan, W. Stable isotopic evidence for climate and basin evolution of the Late Cretaceous Songliao basin, China. Palaeogeogr. Palaeoclim. Palaeoecol. 2013, 385, 106-124. [CrossRef]

10. Gao, Y.; Ibarra, D.E.; Wang, C.S.; Caves, J.K.; Chamberlain, C.P.; Graham, S.A.; Wu, H.C. Mid-latitude terrestrial climate of East Asia linked to global climate in the Late Cretaceous. Geology 2015, 43, 287-290. [CrossRef]

11. Bohacs, K.M.; Carroll, A.R.; Neal, J.E.; Mankiewicz, P.J. Lake-basin type, source potential, and hydrocarbon character; an integrated sequence-stratigraphic-geochemical framework. AAPG Stud. Geol. 2000, 46, 3-34.

12. Song, Z.; Qin, Y.; George, S.; Wang, L.; Guo, J.; Feng, Z. A biomarker study of depositional paleoenvironments and source inputs for the massive formation of Upper Cretaceous lacustrine source rocks in the Songliao Basin, China. Palaeogeogr. Palaeoclim. Palaeoecol. 2013, 385, 137-151. [CrossRef]

13. Wang, L.; Song, Z.; Cao, X.; Li, Y. Compound-specific carbon isotope study on the hydrocarbon biomarkers in lacustrine source rocks from Songliao Basin. Org. Geochem. 2015, 87, 68-77. [CrossRef]

14. Huang, H.; Gao, Y.; Ma, C.; Jones, M.M.; Zeeden, C.; Ibarra, D.E.; Wu, H.; Wang, C. Organic carbon burial is paced by a 173 kyr obliquity cycle in the middle to high latitudes. Sci. Adv. 2021, 7, eabf9489. [CrossRef]

15. Bechtel, A.; Jia, J.; Strobl, S.A.; Sachsenhofer, R.; Liu, Z.; Gratzer, R.; Püttmann, W. Palaeoenvironmental conditions during deposition of the Upper Cretaceous oil shale sequences in the Songliao Basin (NE China): Implications from geochemical analysis. Org. Geochem. 2012, 46, 76-95. [CrossRef]

16. Cao, H.; Hu, J.; Peng, P.; Xi, D.; Tang, Y.; Lei, Y.; Shilling, A. Paleoenvironmental reconstruction of the Late Santonian Songliao Paleo-lake. Palaeogeogr. Palaeoclim. Palaeoecol. 2016, 457, 290-303. [CrossRef]

17. Gao, Y.; Wang, C.; Wang, P.; Gao, Y.; Huang, Y.; Zou, C. Progress on Continental Scientific Drilling Project of Cretaceous Songliao Basin (SK-1 and SK-2). Sci. Bull. 2019, 64, 73-75. [CrossRef]

18. Xu, J.; Liu, Z.; Bechtel, A.; Meng, Q.; Sun, P.; Jia, J.; Cheng, L.; Song, Y. Basin evolution and oil shale deposition during Upper Cretaceous in the Songliao Basin (NE China): Implications from sequence stratigraphy and geochemistry. Int. J. Coal Geol. 2015, 149, 9-23. [CrossRef]

19. Xu, J.; Liu, Z.; Bechtel, A.; Sachsenhofer, R.; Jia, J.; Meng, Q.; Sun, P. Organic matter accumulation in the Upper Cretaceous Qingshankou and Nenjiang Formations, Songliao Basin (NE China): Implications from high-resolution geochemical analysis. Mar. Pet. Geol. 2019, 102, 187-201. [CrossRef] 
20. Gao, Y.; Xi, D.; Qin, Z.; Ma, P.; Wang, C. Clay mineralogy of the first and second members of the Nenjiang Formation, Songliao Basin: Implications for paleoenvironment in the Late Cretaceous. Sci. China Earth Sci. 2018, 61, 327-338. [CrossRef]

21. Xi, D.; Wan, X.; Feng, Z.; Li, S.; Feng, Z.; Jia, J.; Jing, X.; Si, W. Discovery of Late Cretaceous foraminifera in the Songliao Basin: Evidence from SK-1 and implications for identifying seawater incursions. Chin. Sci. Bull. 2011, 56, 253-256. [CrossRef]

22. Huang, Y.; Yang, G.; Gu, J.; Wang, P.; Huang, Q.; Feng, Z.; Feng, L. Marine incursion events in the Late Cretaceous Songliao Basin: Constraints from sulfur geochemistry records. Palaeogeogr. Palaeoclim. Palaeoecol. 2013, 385, 152-161. [CrossRef]

23. Hu, J.F.; Peng, P.A.; Liu, M.Y.; Xi, D.P.; Song, J.Z.; Wan, X.Q.; Wang, C.S. Seawater Incursion Events in a Cretaceous Paleo-lake Revealed by Specific Marine Biological Markers. Sci. Rep. 2015, 5, srep09508. [CrossRef]

24. Cao, H.; Kaufman, A.J.; Shan, X.; Cui, H.; Zhang, G. Sulfur isotope constraints on marine transgression in the lacustrine Upper Cretaceous Songliao Basin, northeastern China. Palaeogeogr. Palaeoclim. Palaeoecol. 2016, 451, 152-163. [CrossRef]

25. Wang, L.; Song, Z.; Yin, Q.; George, S. Paleosalinity significance of occurrence and distribution of methyltrimethyltridecyl chromans in the Upper Cretaceous Nenjiang Formation, Songliao Basin, China. Org. Geochem. 2011, 42, 1411-1419. [CrossRef]

26. Wang, S.; Liu, Z.; Liu, L. Evolution of Songliao Basin and Sea Level Change; Geology Press: Beijing, China, 1994. (In Chinese)

27. Wang, L.; Tian, Y.; Zhao, J. A rapid hydroclimate change and its influence on the Songliao Basin during the Santonian-Campanian transition as recorded by compound-specific isotopes. Palaeogeogr. Palaeoclim. Palaeoecol. 2020, 546, 109674. [CrossRef]

28. Graham, S.A.; Hendrix, M.S.; Johnson, C.L.; Badamgaraw, D.; Badarch, G.; Amory, J.; Porter, M.; Barsbold, R.; Webb, L.E.; Hacker, B.R. Sedimentary record and tectonic implications of Mesozoic rifting in southeast Mongolia. Geol. Soc. Am. Bull. 2001, 113, 1560-1579. [CrossRef]

29. Gao, R.; Zhang, Y.; Cui, T. Cretaceous Petroleum Bearing Strata in the Songliao Basin; Petroleum Industry Press: Beijing, China, 1994; 333p. (In Chinese)

30. Wang, G.; Cheng, R.; Wang, P.; Gao, Y. The Forming Mechanism of Dolostone of Nenjiang Formation in Songliao Basin-Example from CCSD-SKII. Acta Geologica. Sinica. 2008, 1, 48-54. (In Chinese)

31. Deng, C.L.; He, H.Y.; Pan, Y.X.; Zhu, R.X. Chronology of the terrestrial Upper Cretaceous in the Songliao Basin, northeast Asia. Palaeogeogr. Palaeoclim. Palaeoecol. 2013, 385, 44-54. [CrossRef]

32. Wan, X.Q.; Zhao, J.; Scott, R.W.; Wang, P.J.; Feng, Z.H.; Huang, Q.H.; Xi, D.P. Late Cretaceous stratigraphy, Songliao Basin, NE China: SK1 cores. Palaeogeogr. Palaeoclim. Palaeoecol. 2013, 385, 31-43. [CrossRef]

33. Wu, H.; Zhang, S.; Jiang, G.; Hinnov, L.; Yang, T.; Li, H.; Wan, X.; Wang, C. Astrochronology of the Early Turonian-Early Campanian terrestrial succession in the Songliao Basin, northeastern China and its implication for long-period behavior of the Solar System. Palaeogeogr. Palaeoclim. Palaeoecol. 2013, 385, 55-70. [CrossRef]

34. Gao, Y.; Ibarra, D.E.; Rugenstein, J.K.C.; Chen, J.; Kukla, T.; Methner, K.; Gao, Y.; Huang, H.; Lin, Z.; Zhang, L.; et al. Terrestrial climate in mid-latitude East Asia from the latest Cretaceous to the earliest Paleogene: A multiproxy record from the Songliao Basin in northeastern China. Earth Sci. Rev. 2021, 216, 103572. [CrossRef]

35. Feng, Z.-Q.; Jia, C.-Z.; Xie, X.-N.; Shun, Z.; Feng, Z.-H.; Cross, T.A. Tectonostratigraphic units and stratigraphic sequences of the nonmarine Songliao basin, northeast China. Basin Res. 2010, 22, 79-95. [CrossRef]

36. Wu, H.; Lin, T.; Bai, Y.; Zhang, J.; Liu, X.; Huo, Q.; Zhang, Y.; Li, J. Analyses of the mudstone (shale) oil exploration potential in North Songliao Basin. Pet. Geol. Oilfield Dev. Daqing 2019, 38, 78-86.

37. Beckmann, B.; Flögel, S.; Hofmann, P.; Schulz, M.; Wagner, T. Orbital forcing of Cretaceous river discharge in tropical Africa and ocean response. Nat. Cell Biol. 2005, 437, 241-244. [CrossRef]

38. Huang, C.; Hesselbo, S.P.; Hinnov, L. Astrochronology of the late Jurassic Kimmeridge Clay (Dorset, England) and implications for Earth system processes. Earth Planet. Sci. Lett. 2010, 289, 242-255. [CrossRef]

39. Hou, D.; Li, M.; Huang, Q. Marine transgressional events in the gigantic freshwater lake Songliao: Paleontological and geochemical evidence. Org. Geochem. 2000, 31, 763-768. [CrossRef]

40. Shang, F.; Zhou, H.; Liu, Y.; Zhou, X.; Wang, L.; Bi, H.; Wang, G.; Song, L.; Chen, R. A discussion on the organic matter enrichment model of the Nenjiang Formation, Songliao Basin: A case study of oil shale in the 1st and 2nd members of the Nenjiang Formation. Geol. China 2020, 47, 236-248, (In Chinese with English Abstract).

41. Shanks, A.L.; Trent, J.D. Marine snow: Sinking rates and potential role in vertical flux. Deep. Sea Res. Part A Oceanogr. Res. Pap. 1980, 27, 137-143. [CrossRef]

42. Carpenter, S.R. Phosphorus control is critical to mitigating eutrophication. Proc. Natl. Acad. Sci. USA 2008, 105, 11039-11040. [CrossRef] [PubMed]

43. Tian, X.; Gao, Y.; Li, Z.; Carlos, Z.; Chen, Z.; Huang, Y.; Yu, E.; Wang, C. Fine-grained gravity flow deposits and their depositional processes: A case study from the Cretaceous Nenjiang Formation, Songliao Basin, NE China. Geol. J. 2021, 56, 1496-1509. [CrossRef] 